\title{
Freeze Response of Citrus and Citrus- related Genotypes in a Florida Field Planting
}

\author{
Sharon Inch, Ed Stover ${ }^{1}$, and Randall Driggers \\ U.S. Horticultural Research Laboratory, U.S. Department of Agriculture, \\ Agricultural Research Service, 2001 South Rock Road, Fort Pierce, FL \\ 34945
}

Richard F. Lee

National Clonal Germplasm Repository for Citrus and Dates, U.S. Department of Agriculture, Agricultural Research Service, 1060 Martin Luther King Boulevard, Riverside, CA 92521

Additional index words. Aurantioideae, citrus breeding, cold-sensitive, defoliation, dieback, frost damage, Rutaceae, Toddalioideae

\begin{abstract}
A test population consisting of progenies of 92 seed-source genotypes (hereafter called "parent genotypes") of Citrus and Citrus relatives in the field in east-central Florida was assessed after natural freeze events in the winters of 2010 and 2011. Eight seedlings per parent genotype were planted in a randomized complete block design; however, as a result of mortality, the number of plants assessed in some genotype groups was reduced at some or all sampling dates. The citrus diseases huanglongbing and citrus canker were endemic in the planting and may have influenced tree response to cold temperatures. Unusually low temperatures (near $-4{ }^{\circ} \mathrm{C}$ each winter) for east-central Florida were experienced during the trial period. Defoliation and dieback were significantly greater in the winter of 2011 than in the winter of 2010. The winter in 2011 was preceded by a period of extraordinarily low temperatures in mid-December with no period of cool temperatures to allow trees to acclimate. In 2010 the average defoliation was $53 \% \pm 28 \%$ and less than $13 \%$ of the trees exhibited any noticeable dieback, whereas in 2011, the average defoliation and dieback were $93 \% \pm 17 \%$ and $51 \% \pm$ $35 \%$, respectively. Within the genus Citrus, several progenies were identified that had $16 \%$ to $24 \%$ dieback in 2011 and these were from parent genotypes $C$. reticulata (CRC 2590) (23\%), C. sinensis (CRC 3858) (24\%), C. maxima (CRC 3945) (16\%), C. hassaku (CRC 3907 and 3942) (16\% and 17\%), C. aurantium (CRC 628 and 2717$)$ (18\% and 7\%), C. taiwanica (CRC 2588) (21\%), and C. neo-aurantium (C. obovoidea + C. unshiu graft chimera) (CRC 3816) (23\%). Within other genera in the Aurantiodeae, Poncirus trifoliata (CRCs 301, 3957, 3549, and 4007), Severinia buxifolia (CRC 1497), Bergera koenigii (CRC 3165), and Glycosmis pentaphylla (CRC 3285) had the least amount of dieback, all at less than $23 \%$. The two species within the Toddalioideae subfamily of the Rutaceae (Casimiroa edulis and Zanthoxylum ailanthoides) had among the least amount of dieback (1\% and $8 \%$, respectively). When considered by groups, the Citrons and Australian natives had the greatest amount of dieback in $2011,68 \%$ and $65 \%$, respectively. The trifoliates (Poncirus and hybrids) had the least dieback, ranging from $4 \%$ to $40 \%$. The information from this study may be useful in germplasm enhancement and Citrus breeding targeting greater cold tolerance.
\end{abstract}

Citrus is the most economically important fruit tree crop in Florida with an estimated economic value of $\$ 1.35$ billion annually (National Agricultural Statistics Services, 2012). Low temperatures are among the greatest risk factors for U.S. citrus production. Most commercial citrus cultivars are cold-sensitive (Soost and Roose, 1996) and damage will often result when exposed to

\footnotetext{
Received for publication 29 Apr. 2014. Accepted for publication 19 June 2014.

Thanks to Steve Mayo, Sean Reif, Diane Helseth, Scott Ciliento, and Jonathan Worton for their assistance in the field.

${ }^{1}$ To whom reprint requests should be addressed; e-mail Ed.Stover@ars.usda.gov.
}

temperatures below $-2.2{ }^{\circ} \mathrm{C}$ (Yelenosky, $1985)$. In the 1980 s there were multiple severe freeze events in Florida (1981, 1982, 1983, 1985, and 1989) that resulted in crop and yield losses in excess of $\$ 1$ billion U.S. (Tignor et al., 1998). After these extreme freezes, citrus production shifted to the warmer southern parts of the state (Miller, 1991; Yelenosky, 1996). Citrus growers take preventative measures to minimize crop losses from freezes such as use of trunk wraps and water applied through elevated microsprinklers (Bourgeois et al., 1990; Davies et al., 1984; Jackson et al., 1983). However, the effectiveness of these techniques is dependent on wind conditions, types of freezes (advective vs. radiation), water availability, and tree and grove size (Bourgeois et al., 1990; Ebel et al., 2005). Protection using microsprinklers is compromised by high wind speeds (Nisbitt et al., 2000). Developing more cold-tolerant citrus varieties through breeding and selection has long been considered the most effective long-term solution (Grosser et al., 2000; Yelenosky, 1985).

Citrus and Citrus relatives are members of the family Rutaceae. The subtribe Citrinae is composed of Citrus (mandarins, oranges, pummelos, grapefruits, papedas, limes, lemons, citrons, and sour oranges); Poncirus (deciduous trifoliate oranges); Fortunella (kumquats); Microcitrus and Eremocitrus (both Australian natives); and Clymenia (Penjor et al., 2013). There is considerable morphological and ecological variation within this group. With Citrus, cold-hardiness ranges from cold-tolerant to cold-sensitive (Soost and Roose, 1996). Poncirus and Fortunella are considered the most cold-tolerant genera that are cross-compatible with Citrus. Poncirus trifoliata reportedly can withstand temperatures as low as $-30^{\circ} \mathrm{C}$ with proper acclimation (Lang et al., 2005) and is used as a cold-tolerant rootstock for some commercial citrus production (Ebel et al., 2008; Tignor et al., 1998). The most cold-tolerant commercial Citrus variety is considered C. unshiu (Satsuma mandarin), whereas $C$. aurantifolia Swing. (Mexican Lime), C. limon L. Burm. $f$. (Lemon), and C. medica L. (Citron) are considered the most susceptible to freeze damage (Davies and Albrigo, 1994; Grosser et al., 1998).

A period of acclimation is important for inducing cold tolerance in Citrus. Cold tolerance in many plant species is not constitutively expressed; it is induced in response to reduction in daylength and the exposure to non-freezing chilling temperatures. Periods of warm weather before a freeze event will make citrus plants less cold-acclimated and thus more susceptible to the freezing conditions (Davies and Albrigo, 1994). Gene expression differences during acclimation have been associated with freeze tolerance in Citrus (He et al., 2012; Lang et al., 2005; Zhang et al., 2005). Genes for cold tolerance have been identified in $P$. trifoliata, $C$. grandis $(=C$. maxima $), C$. paradisi, $C$. sinensis, and $C$. jambhiri (Champ et al., 2007; He et al., 2012; Long et al., 2012; Sahin-Çevik and Moore, 2006; Webber et al., 2003). Use of cold-tolerant rootstocks such as Poncirus can increase the expression of cold tolerance associated genes in cold-tolerant scions (Ebel et al., 2005; Huang et al., 2011; Yelenosky and $\mathrm{Vu} ; 1992$ ).

Non-cultivated Citrus and Citrus relatives have economically important traits that could be extremely valuable in the development of new cultivars (Grosser and Gmitter, 1990). Breeding within the Citrus genepool is complicated by many factors including prolonged juvenility, self- and cross-incompatibility, polyembryony (apomixis), heterozygosity, and inbreeding depression (Grosser and Gmitter, 1990; Soost and Cameron, 1975; Soost and Roose, 1996). However, genetic transformation techniques such as protoplast 


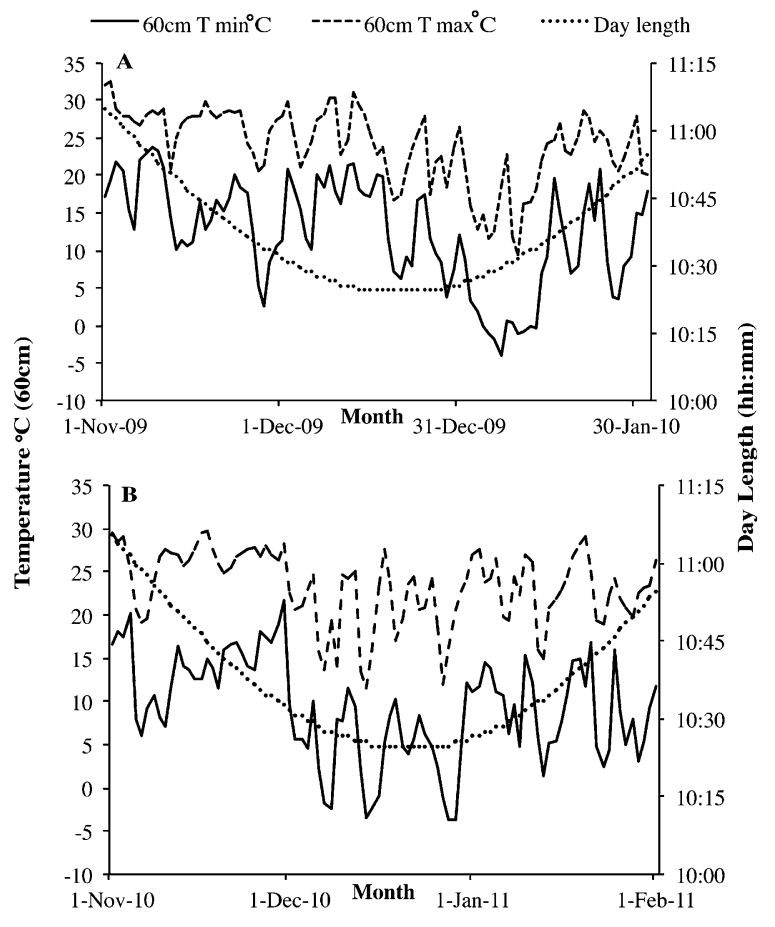

Fig. 1. Day length (hh:mm) and minimum and maximum temperatures $\left({ }^{\circ} \mathrm{C}\right)$ for Fort Pierce, FL, in $(\mathbf{A})$ Winter 2010 (1 Nov. 2009 to 30 Jan. 2010) and (B) Winter 2011 (1 Nov. 2010 to 30 Jan. 2011).

transformation (Fleming et al., 2000; Grosser and Gmitter, 1990), particle bombardment (Yao et al., 1996), and Agrobacterium-mediated transformation (Luth and Moore, 1999; Moore et al., 1992) may be used to develop genotypes with cold resistance genes from distant relatives but with desired fruit quality.

The objective of this study was to survey genotypes within the Rutaceae for freeze damage as an indication of cold tolerance. Seedlings from 92 highly diverse seed-source genotypes were exposed to natural freeze events in east-central Florida. Defoliation and dieback were assessed in the winters of 2010 and 2011.

\section{Materials and Methods}

Seeds from Citrus and Citrus hybrids were obtained from the USDA-ARS National Clonal Germplasm Repository for Citrus and Dates (NCGRCD) at the University of California at Riverside (UCR), Riverside, CA ( $<$ http://www.citrusvariety.ucr.edu $>$ ). This collection contains over 1100 accessions, each one identified by a unique Citrus Research Center (CRC) number. The names and species designations reported here are those used by the NCGRCD at the time of publication. In this study, seeds from 124 accessions were initially acquired representing $\approx 85 \%$ of the genetic diversity within the UCR collection (Barkley, 2003). The phylogenetic relationships of the parent genotypes used are described in Barkley (2003) and Bayer et al. (2009). Seeds of Afraegle paniculata (Schum.) Engl. and Aegle marmelos (L.) Corr (subfamily Aurantioideae), and Casimiroa edulis (Llave et Lex, subfamily Toddalioideae) were obtained from the Fruit and Spice Park (Miami/Dade County, FL). Zanthoxylum ailanthoides (L.) (subfamily Toddalioideae) was obtained from the University of Georgia. Within the Rutaceae, nucellar embryony varies greatly (Frost and Soost, 1968); therefore, the progeny included in this study were either genetically identical to the maternal parent or half-sib hybrids with a known seed parent and an undetermined pollen parent.

Under greenhouse conditions at the USDA-ARS U.S. Horticultural Research Laboratory in Fort Pierce, FL, seeds of 92 of the 124 seed-source accessions were successfully propagated in individual plastic cells $(3.8 \times 21 \mathrm{~cm})(\mathrm{SC}-10$ super cell Cone-tainers; Stuewe and Sons, Corvallis, OR) containing sterile potting mix. After 4 to 7 months, the seedlings were transferred to 3.7-L containers, which were watered daily and fertilized on a weekly basis. The maximum and minimum diurnal temperatures of the greenhouse were 35 and $23{ }^{\circ} \mathrm{C}$ in the summer and 32 and $20{ }^{\circ} \mathrm{C}$ in the winter. In June and July 2009, the 6- to 9-month-old seedlings were planted $0.6 \mathrm{~m}$ apart in three rows ( $3.5 \mathrm{~m}$ apart) at the USDA-ARS, Fort Pierce, FL, farm. The planting was established as a randomized complete block design.

Two weeks after freeze events in Jan. 2010 , the percentage defoliation $(1 \%$ to $100 \%$ ) was visually estimated on each tree and presence or absence of dieback ( 0 or 1$)$ was recorded. In 2011, plants were rated for percentage defoliation $(1 \%$ to $100 \%)$ in February. Percentage of canopy dieback $(1 \%$ to $100 \%)$ was visually estimated on each plant in May. Weather data for 2010 and 2011 were collected using the Florida Automated Weather Network (FAWN) for the Ft.
Pierce site, which was $3.2 \mathrm{~km}$ from the test plot. A weather station on the farm site indicated temperatures within $0.5{ }^{\circ} \mathrm{C}$ of the FAWN data on each freeze night. Microsprinklers were run during the freeze events but were at ground level as used for standard irrigation.

Statistical analyses were performed with $\mathrm{JMP}^{\circledR}$ Version 11 (SAS Institute Inc., 2013). The data were not normally distributed and did not meet the assumptions for analysis of variance. Therefore, nonparametric statistical methods were used to analyze the data. Means were calculated for defoliation and dieback for seedlings of each of the parent genotypes and of each of the genotypic groups. Genotypic groups were assigned based on pedigree of $50 \%$ or more of a non-Citrus genus or distant Citrus relative, and within Citrus only by a pedigree of $60 \%$ or more of the indicated species group. Designation of pummelo/mandarin hybrid was chosen for parent genotypes, which were predominately comprised of equal portions of C. maxima (pummelo) and $C$. reticulata (mandarin), except that sour oranges (generally $50 \%$ pummelo and 50\% mandarin) were maintained as a group based on their distinct phenotype. Differences in percentage defoliation and dieback within years were compared using the Wilcoxon/Kruskal-Wallis test (rank sums) and $\chi^{2}$ test. Spearman correlations were calculated to determine if defoliation and dieback were correlated within individual trees in each of the years.

\section{Results}

Winter of 2010. In the winter of 2010 , freezing temperatures were recorded between 5 and $12 \mathrm{Jan}$. with the lowest temperature of $-4{ }^{\circ} \mathrm{C}$ on 7 Jan. (Fig. 1A). After these freeze events, average defoliation was $53 \% \pm 28 \%$ and ranged from $14 \%$ to $100 \%(\mathrm{n}=522$ plants). $P$. trifoliata and its hybrids were recorded as having the greatest amount of defoliation $(83 \%)$, but $P$. trifoliata is fully deciduous and its hybrids are partially deciduous in most winters. All other parent genotypes/groups assessed in this study are fully non-deciduous (evergreen). Even with the $P$. trifoliata and its hybrids removed, there were significant differences in defoliation among parent genotypes $\left(\chi^{2}=298, \mathrm{df}=\right.$ $69, P<0.0001)$. As a group, the Citrons had the lowest average level of defoliation $(18 \%)$ (Fig. 2A). Within Citrus, C. medica (CRCs 3546 and 661) had the lowest defoliation at $14 \%$. Seven other Citrus genotypes had less than $35 \%$ defoliation and included $C$. reticulata (CRC 3260), C. medica (CRC 3523), C. excelsa (CRC 2317), C. macrophylla (CRC 3842), C. limonia (CRC 712), C. volkameriana $\times$ C. limonia $(\mathrm{CRC} 3050)$, and $\times$ Citrofortunella (CRC 3172) (Table 1). Among the genera in the Aurantiodeaea that are not cross-compatible with Citrus (hereinafter named the "other Aurantiodeae" group), Murraya paniculata (CRC 1637) had the lowest amount of defoliation, $18 \%$ (Table 1). Other genera of relatives with less than $35 \%$ defoliation 
Table 1. Average defoliation (\%) and dieback (\%) of progenies of 92 Citrus and Citrus relative seed source genotypes exposed to freezing temperatures in the field in Fort Pierce, FL, in the winter of 2010 (1 Nov. 2009 to 30 Jan. 2010) and the Winter 2011 (1 Nov. 2010 to 30 Jan. 2011). ${ }^{\mathrm{z}}$

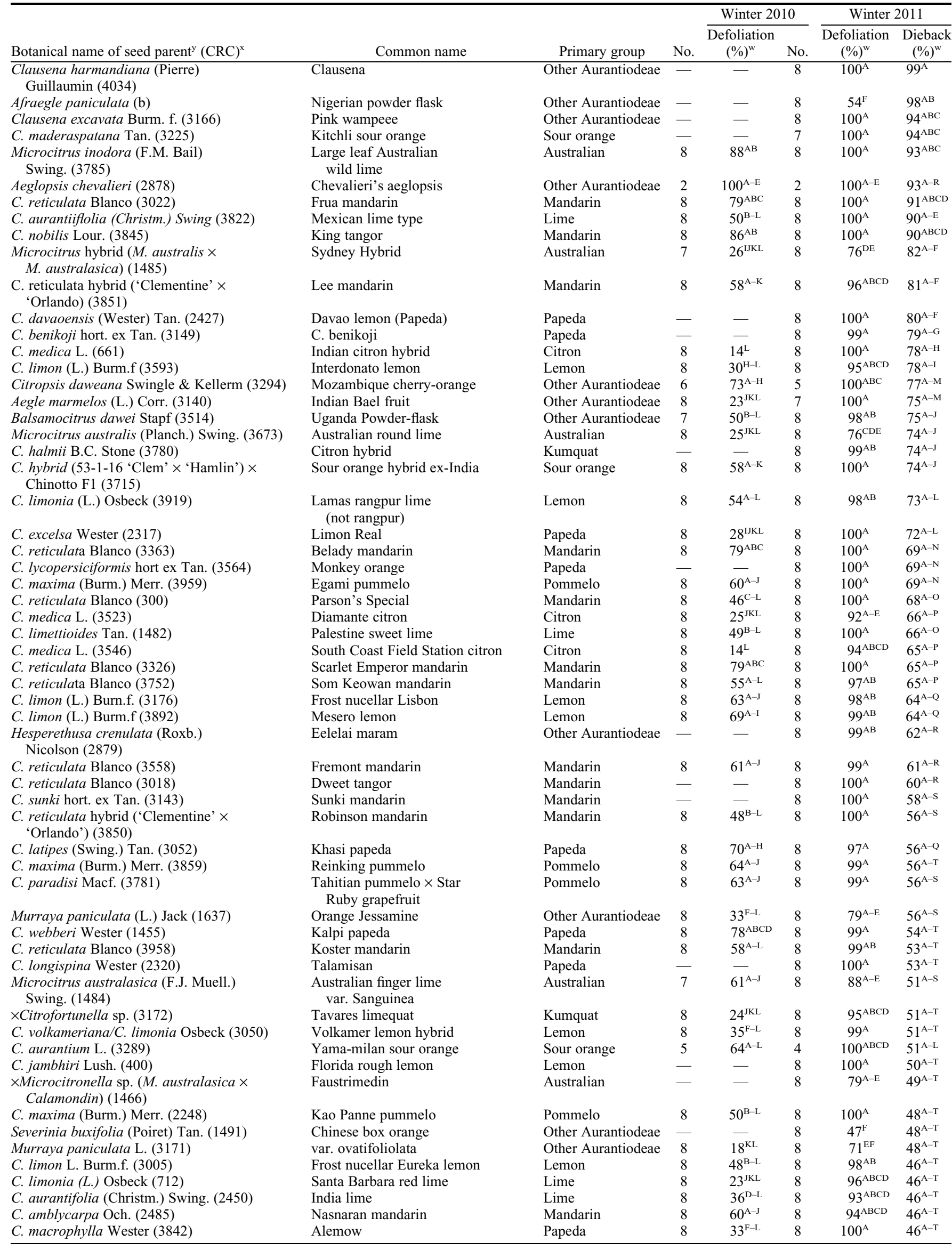


Table 1. (Continued) Average defoliation (\%) and dieback (\%) of progenies of 92 Citrus and Citrus relative seed source genotypes exposed to freezing temperatures in the field in Fort Pierce, FL, in the winter of 2010 (1 Nov. 2009 to 30 Jan. 2010) and the Winter 2011 (1 Nov. 2010 to 30 Jan. 2011 ). ${ }^{z}$

\begin{tabular}{|c|c|c|c|c|c|c|c|}
\hline \multirow[b]{2}{*}{ Botanical name of seed parent ${ }^{y}(C R C)^{x}$} & \multirow[b]{2}{*}{ Common name } & \multirow[b]{2}{*}{ Primary group } & \multirow[b]{2}{*}{ No. } & \multicolumn{2}{|c|}{ Winter 2010} & \multicolumn{2}{|c|}{ Winter 2011} \\
\hline & & & & $\begin{array}{l}\text { Defoliation } \\
(\%)^{\mathrm{w}}\end{array}$ & No. & $\begin{array}{l}\text { Defoliation } \\
(\%)^{\mathrm{w}}\end{array}$ & $\begin{array}{l}\text { Dieback } \\
(\%)^{\mathrm{w}}\end{array}$ \\
\hline C. limon (L.) Burm. f. (3885) & Local variety from Iran & Lemon & 8 & $36^{\mathrm{D}-\mathrm{L}}$ & 8 & $97^{\mathrm{ABC}}$ & $44^{\mathrm{A}-\mathrm{T}}$ \\
\hline $\begin{array}{l}\text { Eremocitrus glauca (Lindley) } \\
\quad \text { Swing. Hybrid (4105) }\end{array}$ & Australian desert lime hybrid & Australian & 8 & $58^{\mathrm{A}-\mathrm{K}}$ & 8 & $83^{\mathrm{A}-\mathrm{E}}$ & $43^{\mathrm{B}-\mathrm{T}}$ \\
\hline C. reticulata Blanco (4003) & Sun Chu Sha mandarin & Mandarin & - & - & 8 & $98^{\mathrm{AB}}$ & $41^{\mathrm{B}-\mathrm{T}}$ \\
\hline C. neo-aurantium Tan. (3611) & Konejime sour orange hybrid & Sour orange & 8 & $43^{\mathrm{C}-\mathrm{L}}$ & 8 & $96^{\mathrm{ABCD}}$ & $40^{\mathrm{C}-\mathrm{T}}$ \\
\hline$\times$ Citroncirus sp. (3552) & S-281 Citrangelo & Trifoliate & 8 & $88^{\mathrm{AB}}$ & 8 & $100^{\mathrm{A}}$ & $40^{\mathrm{C}-\mathrm{T}}$ \\
\hline C. aurantium L. (3929) & Gou Tou Cheng & Sour orange & 8 & $63^{\mathrm{A}-\mathrm{J}}$ & 8 & $98^{\mathrm{AB}}$ & $39^{\mathrm{C}-\mathrm{T}}$ \\
\hline C. maxima (Burm.) Merr. (4026) & Pomelit & Pommelo/mandarin & 8 & $64^{\mathrm{A}-\mathrm{J}}$ & 8 & $99^{\mathrm{A}}$ & $36^{\mathrm{D}-\mathrm{T}}$ \\
\hline C. reticulata Blanco (3812) & Unnamed mandarin & Mandarin & - & - & 8 & $93^{\mathrm{ABCD}}$ & $35^{\mathrm{E}-\mathrm{T}}$ \\
\hline C. leiocarpa hort ex Tan. (3147) & Koji mandarin & Papeda & - & - & 8 & $91^{\mathrm{A}-\mathrm{E}}$ & $34^{\mathrm{E}-\mathrm{T}}$ \\
\hline C. reticulata Blanco (3260) & Soh niamtra mandarin & Mandarin & 8 & $31^{\mathrm{G}-\mathrm{L}}$ & 8 & $95^{\mathrm{ABCD}}$ & $33^{\mathrm{F}-\mathrm{T}}$ \\
\hline C. maxima (Burm.) Merr. (2242) & Kao Pan pummelo & Pommelo & 8 & $56^{\mathrm{A}-\mathrm{K}}$ & 8 & $97^{\mathrm{ABC}}$ & $33^{\mathrm{F}-\mathrm{T}}$ \\
\hline C. aurantium L. (3930) & Zhuluan sour orange hybrid & Sour orange & 8 & $76^{\mathrm{A}-\mathrm{E}}$ & 8 & $91^{\mathrm{A}-\mathrm{E}}$ & $33^{\mathrm{F}-\mathrm{T}}$ \\
\hline C. intermedia hort ex Tan. (3474) & Konejime sour orange hybrid & Sour orange & 8 & $59^{\mathrm{A}-\mathrm{K}}$ & 8 & $99^{\mathrm{AB}}$ & $32^{\mathrm{F}-\mathrm{T}}$ \\
\hline C. sinensis (L.) Osbeck (3858) & Pineapple sweet orange & Mandarin & 8 & $59^{\mathrm{A}-\mathrm{K}}$ & 8 & $99^{\mathrm{A}}$ & $24^{\mathrm{G}-\mathrm{T}}$ \\
\hline C. reticulata Blanco (2590) & Tien Chieh mandarin & Mandarin & 8 & $59^{\mathrm{A}-\mathrm{K}}$ & 8 & $91^{\mathrm{A}-\mathrm{E}}$ & $23^{\mathrm{I}-\mathrm{T}}$ \\
\hline Bergera koenigii L. (3165) & Curry leaf & Other Aurantiodeae & 8 & $36^{\mathrm{D}-\mathrm{L}}$ & 8 & $100^{\mathrm{A}}$ & $23^{\mathrm{J}-\mathrm{T}}$ \\
\hline $\begin{array}{l}\text { C. neo-aurantium (C. obovoidea }+ \\
\text { C. unshiu graft chimera) ( } 3816)\end{array}$ & Kinkoji Unshiu graft chimera & Sour orange & - & - & 8 & $94^{\mathrm{ABCD}}$ & $23^{\mathrm{H}-\mathrm{T}}$ \\
\hline C. taiwanica Tan. \& Shimada (2588) & Nansho Daidai sour orange & Sour orange & 8 & $74^{\mathrm{A}-\mathrm{F}}$ & 8 & $97^{\mathrm{ABCD}}$ & $21^{\mathrm{J}-\mathrm{T}}$ \\
\hline C. aurantium L. (628) & Standard sour orange & Sour orange & - & - & 7 & $98^{\mathrm{AB}}$ & $18^{\mathrm{J}-\mathrm{T}}$ \\
\hline C. hassaku hort ex Tan. (3907) & Hassaku pummelo hybrid & Pommelo/mandarin & 8 & $76^{\mathrm{A}-\mathrm{E}}$ & 8 & $89^{\mathrm{A}-\mathrm{E}}$ & $17^{\mathrm{M}-\mathrm{T}}$ \\
\hline Glycosmis pentaphylla (Retz.) Corr. (3285) & Orange berry & Other Aurantiodeae & 8 & $31^{\mathrm{G}-\mathrm{L}}$ & 8 & $53^{\mathrm{F}}$ & $17^{\mathrm{M}-\mathrm{T}}$ \\
\hline C. maxima (Burm.) Merr. (3945) & Mato Buntan pummelo & Pommelo & - & - & 7 & $85^{\mathrm{A}-\mathrm{E}}$ & $16^{\mathrm{K}-\mathrm{T}}$ \\
\hline C. hassaku hort ex Tan. (3942) & Hassaku pummelo hybrid & Pommelo/mandarin & 8 & $59^{\mathrm{A}-\mathrm{K}}$ & 8 & $100^{\mathrm{A}}$ & $16^{\mathrm{N}-\mathrm{T}}$ \\
\hline Poncirus trifoliata L. (4007) & "Little-leaf" trifoliate & Trifoliate & 8 & $94^{\mathrm{A}}$ & 8 & $99^{\mathrm{A}}$ & $14^{\mathrm{O}-\mathrm{T}}$ \\
\hline Severinia buxifolia (Poiret) Tan. (1497) & Chinese box orange (brachytic form) & Other Aurantiodeae & - & - & 8 & $7^{\mathrm{E}}$ & $11^{\mathrm{P}-\mathrm{T}}$ \\
\hline Poncirus trifoliata L. (3549) & Simmons trifoliate & Trifoliate & - & - & 8 & $100^{\mathrm{A}}$ & $8^{\mathrm{RST}}$ \\
\hline C. aurantium L. (2717) & Olivelands sour orange & Sour orange & 8 & $39^{\mathrm{C}-\mathrm{L}}$ & 8 & $93^{\mathrm{ABCD}}$ & $7^{\mathrm{RST}}$ \\
\hline Zanthoxylum ailanthoides L. (a) & Japanese prickly-ash & Toddalioideae & 8 & $100^{\mathrm{A}}$ & 8 & $100^{\mathrm{B}}$ & $7^{\text {QRST }}$ \\
\hline $\begin{array}{l}\times \text { Citroncirus sp. }(C \text {. paradisi 'Duncan' } \times P \text {. } \\
\quad \text { trifoliata })(3771)\end{array}$ & Swingle citrumelo & Trifoliate & 8 & $73^{\mathrm{A}-\mathrm{G}}$ & 8 & $96^{\mathrm{ABCD}}$ & $5^{\mathrm{sT}}$ \\
\hline$\times$ Citroncirus sp. $(301)$ & Rusk citrange trifoliate hybrid & Trifoliate & 8 & $78^{\mathrm{ABCD}}$ & 8 & $96^{\mathrm{ABCD}}$ & $4^{\mathrm{ST}}$ \\
\hline $\begin{array}{l}\times \text { Citroncirus sp. ('Cleopatra' mandarin } \times \\
\text { trifoliate) }(3957)\end{array}$ & Trifoliate & Trifoliate & 8 & $94^{\mathrm{A}}$ & 8 & $93^{\mathrm{ABCD}}$ & $4^{\mathrm{RST}}$ \\
\hline Casimiroa edulis Llave \& Lex (c) & White Sapote & Toddalioideae & 8 & $18^{\mathrm{KL}}$ & 8 & $54^{\mathrm{CD}}$ & $1^{\mathrm{T}}$ \\
\hline
\end{tabular}

${ }^{\mathrm{z}}$ The table is sorted based on dieback observed during Winter 2011.

yBotanical and common names specified by Citrus Variety Collection, Riverside, CA (<http://www.citrusvariety.ucr.edu $>$ ).

${ }^{\mathrm{x}}$ Accession number assigned by Citrus Research Center and now maintained by the UC Riverside Citrus Variety Collection.

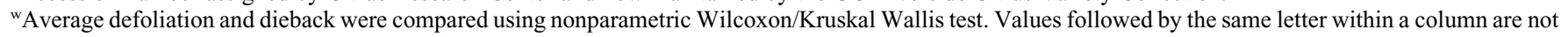
significantly different at $P=0.05$.

included Microcitrus australis (CRC 3673), Microcitrus hybrid (M. australis $\times$ M. australasica) (CRC 1485), Hesperethusa crenulata (CRC 2879), Murraya paniculata (CRC 3171), and Glycosmis pentaphylla (CRC 3285). Aeglopsis chevalier (CRC 2878) had the greatest amount of defoliation, $100 \%$ (Table 1). In 2010, dieback was also different among parent genotypes $\left(\chi^{2}=96\right.$, $\mathrm{df}=91, P=0.014)$. Less than $13 \%$ of the total plants exhibit signs of dieback (based on present or absent). The Australian natives had the greatest amount of dieback; $21 \%$ of the plants in this group showed some dieback (Fig. 2A). All of the plants in 2010 recovered (data not shown).

Winter of 2011. Preceding the winter of 2011, on 8 Dec. 2010, the temperature rapidly dropped to $-2.5{ }^{\circ} \mathrm{C}$ followed by two more freeze events below $-2.5{ }^{\circ} \mathrm{C}$ on 14 and 28 Dec. with the lowest temperature recorded at $-3.7^{\circ} \mathrm{C}$ (Fig. 1B). Average defoliation was significantly higher in 2011 than in 2010 and ranged from $100 \%$ to $7 \%$ with an average of $93 \% \pm 17 \%(n=719)$. There were significant differences among progenies of parent genotypes in defoliation $\left(\chi^{2}=374\right.$, df $=91, P<$
$0.0001)$ and dieback $\left(\chi^{2}=383, \mathrm{df}=91, P<\right.$ $0.0001)$. Analyzed as groups, the "true" citrus had the greatest amount of defoliation, ranging from $95 \%$ to $98 \%$. The "other Aurantiodeae" showed the least amount of defoliation at $80 \%$ (Fig. 2B), but this was largely the result of the low defoliation in Severinia with seedlings of accessions Severinia buxifolia (CRC 1497) showing significantly less defoliation (7\%) than all others in the trial. The other Citrus-related genera (including the other Aurantiodeae, Toddalioideae, and Australian natives) with less than $80 \%$ defoliation included Microcitrus australis (CRC 8673), Murraya paniculata (CRCs1637 and 3171), Glycosmis pentaphylla (3285), and Casimiroa edulis (Table 1). In these groups, progeny of the Microcitrus hybrids CRCs 1485 and 1466 had the least amount of defoliation, $76 \%$ and $78 \%$, respectively (Table 1).

There was much greater dieback in 2011 than in 2010. In 2011, average dieback was $49 \%$ and ranged from $99 \%$ to $1 \%$ (Table 1 ). Casimiroa edulis and Zanthoxylum ailanthoides, within the Toddalioideae subfamily, had very low amounts of dieback at $1 \%$ and 7\%. Within the Aurantiodeae, Poncirus trifoliata and hybrids were lowest ranging from $4 \%$ to $40 \%$ dieback. Within the groups of the genus Citrus, several parent genotypes had less than $25 \%$ dieback and included $C$. reticulata (CRC 2590), $C$. sinensis (CRC 3858), C. maxima (CRC 3945), C. hassaku (CRC 3907 and 3942), C. aurantium (CRC 628 and 2717), C. taiwanica (CRC 2588), and C. neoaurantium (CRC 3816). Within the "other Aurantiodeae" group, Severinia buxifolia (CRC 1497), Bergera koenigii (CRC 3165), and Glycosmis pentaphylla (CRC 3285) had less than 25\% dieback (Table 1). Analyzed as groups, the Citrons and Australian natives had the greatest amount of dieback, $68 \%$ and $66 \%$, respectively. Pummelo/mandarin hybrids, trifoliates, and Toddalioideae had the least amount of dieback, $16 \%, 13 \%$, and $4 \%$, respectively (Fig. 2B). Defoliation and dieback within individual trees were positively correlated in the winter of 2011 (Spearman's $\rho=0.4591, P<$ $0.0001)$. Mortality resulting from freeze events in 2011 resulted in loss of $8.1 \%$ of the trees. 
A

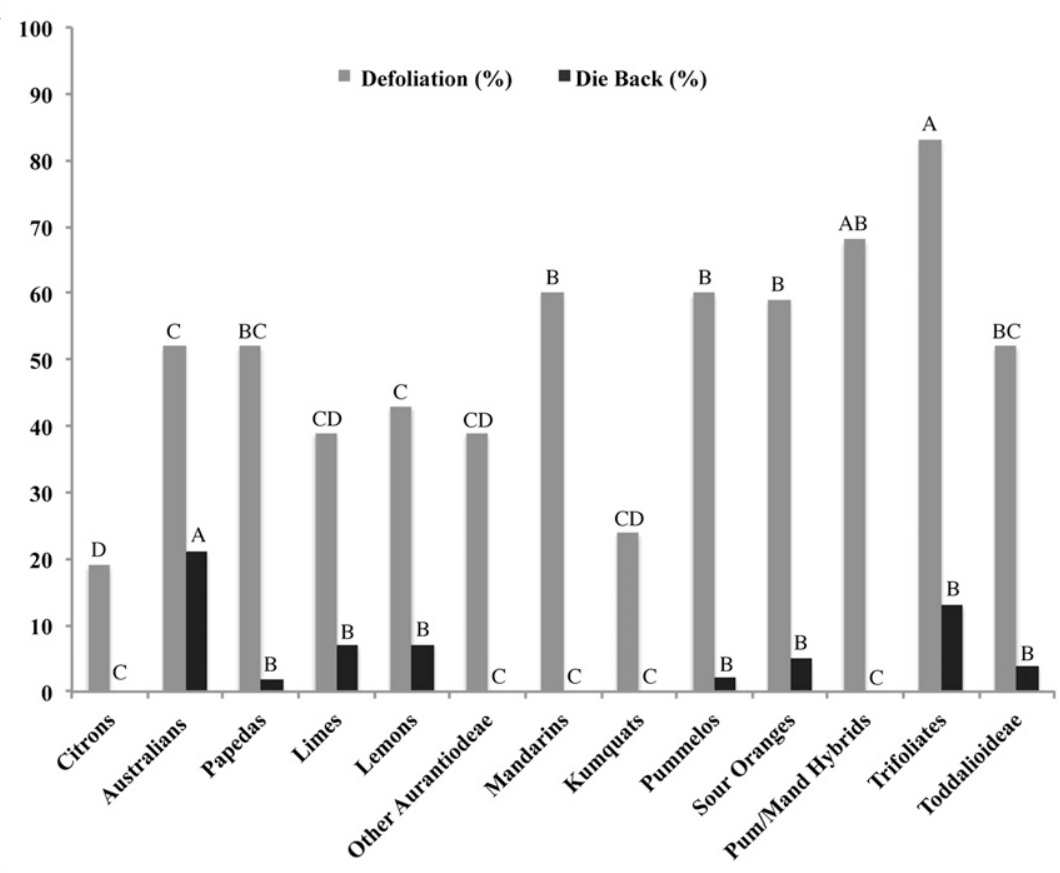

B

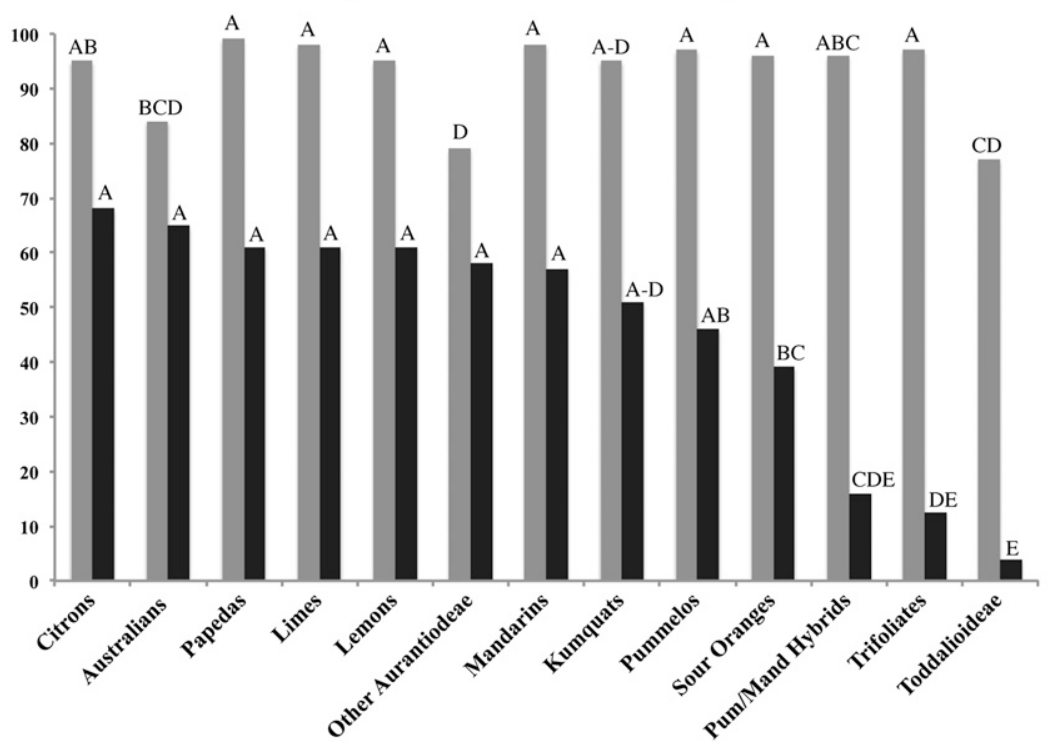

Fig. 2. Average defoliation (\%) and dieback (\%) of citrus taxonomic groups for progenies of 94 Citrus and Citrus relative seed source genotypes exposed to freezing temperatures in the field in Fort Pierce, FL, in (A) Winter 2010 and (B) Winter 2011. Means within years were compared using the Wilcoxon/ Kruskal-Wallis non-parametric means separation test.

\section{Discussion}

In this study, defoliation and dieback were used to determine the response to cold temperatures in Citrus and Citrus relatives when exposed to natural freeze events in Florida. However, one of the problems with using defoliation as a measure of cold tolerance is that some of the varieties/species used in this study, including Poncirus trifoliata and associated hybrids, are deciduous or semideciduous. Also, it can be a healthy citrus response to drop leaves when exposed to freezing temperatures that damage leaves but not stems, and failure to drop leaves after such conditions reflects more serious damage (Ketchie, 1969). Stem damage is generally a better measure of cold tolerance (Cooper et al., 1955; Ketchie, 1969). Stems tend to be the more cold-tolerant than leaves or fruit (Hendershott, 1962). A measure of electrolyte leakage is considered the best measure (Yelenosky, 1975). However, this method is not feasible in large-scale field trials.

In the Florida citrus community, there is a widely accepted view that "no two freezes are ever the same." Tree responses are affected by differences in factors such as acclimation conditions (Yelenosky and $\mathrm{Vu}$, 1992), rate of temperature change before and after the hard freeze, wind conditions, and time of occurrence within the seasonal span of tree quiescence. Damage in commercial Florida citrus trees is typically expected after
4 or more hours below $-2.2{ }^{\circ} \mathrm{C}$ (Yelenosky, 1996). It is noteworthy that citrus in California is much more regularly exposed to freezing temperatures than citrus in Florida, and usually there is little tree damage, likely as a result of sustained cool temperatures in the fall and winter that maintain tree quiescence. The Lindsay, CA, weather station (typical of Central Valley, CA, citrus production) indicates 13 of 16 years and 309 total days with sub-freezing temperatures in 1998-2013 (UC IPM Online, 2014), and in the same period, there were 9 of 16 years and $96 \mathrm{~d}$ with temperatures below the $-2.2{ }^{\circ} \mathrm{C}$ Florida citrus damage threshold. In the Lindsay, CA, 1998-2013 weather data set, the December median low is $1.7^{\circ} \mathrm{C}$ and average low is $1.8^{\circ} \mathrm{C}$; January median low is $2.8^{\circ} \mathrm{C}$ and average low is $2.5^{\circ} \mathrm{C}$ (Table 2 ).

In contrast, for the Ft. Pierce, FL, 1998-2013 FAWN weather data set, the December median low is $13.5^{\circ} \mathrm{C}$ and average low is $12.5^{\circ} \mathrm{C}$; January median low is $10.7^{\circ} \mathrm{C}$ and average low is $10.0^{\circ} \mathrm{C}$. In Fort Pierce data for this 16-year period, freezing temperatures have been recorded in seven of the 16 winters, for a total of $35 \mathrm{~d}$. Temperatures below the $-2.2{ }^{\circ} \mathrm{C}$ thresholds have been observed in only three of 16 winters, and two coincided with the years of this study, in Jan. 2010 and Dec. 2010 (Table 2). The 2010 freeze events were the only December freezes recorded at the Fort Pierce FAWN station in 16 years of operation. The low temperature averaged $8.5{ }^{\circ} \mathrm{C}$ for the week before the first freeze and averaged $16.4{ }^{\circ} \mathrm{C}$ for the last week of November, making it highly likely that the freeze events occurred before the plants were acclimated. This might have contributed to the marked defoliation and dieback in 2011. The age and size of trees will affect the degree to which the plants are acclimated, and younger trees are generally less cold-tolerant than older trees (Yelenosky, 1996). The seedlings in this study were only 1 to 2 years old when exposed to natural freeze events. Therefore, they were likely more susceptible to cold damage than they would have been if they were more mature at the times of exposure.

As temperatures approach a critical threshold, even slight differences in temperature may have a large effect on resulting tree damage. Therefore, effects such as trapping of warmer air within the canopy, differences in stem diameter that affect temperature change, and microclimate differences may influence damage. These differences likely contributed to the variability leading to modest statistical mean separation within this experiment so that approximately half of the parental genotypes were not statistically different $(\alpha=0.05)$ from the one with lowest dieback and approximately half were not statistically different from the one with highest dieback.

There have been a number of studies on cold-hardiness of citrus. Although there were some notable differences, in many cases, their reports were consistent with our observations. Trifoliates are generally reported to 
Table 2. Freezing temperature-related data for 1998-2013 for the location of this study in Ft. Pierce, FL, and a typical California citrus area in Lindsay, CA.

\begin{tabular}{lcc}
\hline & Ft. Pierce, $\mathrm{FL}^{\mathrm{z}}$ & Lindsay, $\mathrm{CA}^{\mathrm{y}}$ \\
\hline December average low temp. $\left({ }^{\circ} \mathrm{C}\right)$ & 12.5 & 1.8 \\
December median low temp. $\left({ }^{\circ} \mathrm{C}\right)$ & 13.5 & 1.7 \\
Jan. median low temp. $\left({ }^{\circ} \mathrm{C}\right)$ & 10 & 2.5 \\
Jan. average low temp. $\left({ }^{\circ} \mathrm{C}\right)$ & 10.7 & 2.8 \\
Years below $0{ }^{\circ} \mathrm{C}$ (no.) & 7 & 13 \\
Years below $-2.2^{\circ} \mathrm{C}$ (no.) & 3 & 9 \\
Days below $0{ }^{\circ} \mathrm{C}$ (no.) & 35 & 309 \\
Days below $-2.2^{\circ} \mathrm{C}$ (no.) & 8 & 96 \\
\hline
\end{tabular}

${ }^{2}$ Data are from the Florida Automated Weather Network (FAWN, 2014).

${ }^{\mathrm{y}}$ Data are from UC IPM Online (2014).

be the most cold-tolerant followed by kumquats and Satsuma mandarins. Sour oranges, tangerines, tangelos, sweet oranges, and grapefruit are generally intermediate in cold-hardiness. Lemons, limes, and citrons are generally the least cold-tolerant (Rieger et al., 2003). In our study, P. trifoliata and its hybrids were some of the most cold-tolerant seed parents as assessed by dieback in 2011 . By all measures in this study, within the Citrus gene pool, the kumquat group was always in the least cold-damaged statistical grouping. Within the groups of genus Citrus, the pummelo/mandarin hybrids and sour oranges (which are also pummelo/mandarin hybrids) were in the statistical group with the least dieback. Contrary to the low cold tolerance typically reported, the citron group in 2010 had the least amount of defoliation; however, in 2011, the citrons had the greatest amount of dieback and defoliation. The freeze events in 2010 were less severe than in 2011, which may account for the differences in the response to cold temperatures.

One of the limitations of broad-scale screening for cold-tolerant genes among Citrus relatives is the small number of accessions in genera related to Citrus (Barkley, 2003; Bayer et al., 2009). Many of the distant Citrus relatives used in this study, including Severinia, Glycosmis, and Casimiroa, were among the most cold-tolerant. These species do not readily cross with Citrus. Cross-compatibility tends to decrease as distance increases among taxa as a result of pre-zygotic and post-zygotic barriers to hybridization (Ladizinsky, 1992). There has been very little successful intergeneric sexual hybridization between the Aurantioideae and Toddaliodaea. However, use of biotechnology has generated intergeneric somatic hybrids of some sexual-incompatible taxa such as $C$. senensis 'Hamlin' combined with Severinia disticha and Citropsis gillentiana, Citrus + Citropsis, and Citrus + Severinia (Grosser et al., 1990, 1998; Grosser and Gmitter, 1990; Medina-Filho et al., 1998). These approaches may permit integration of genes for cold-hardiness.

It is noteworthy that the lowest dieback in the Citrus genepool in 2011 was observed for seedlings with parental genotypes including Poncirus trifoliata or hybrids of pummelo $x$ mandarin (including sour orange types). Only one parental genotype with Poncirus in its pedigree (CRC3552) showed more than 14\% dieback, and two parental genotypes that were Poncirus $\times$ cultivated Citrus displayed only 4\% dieback. Poncirus and Citrus are sexually and graft-compatible (Gmitter, 1994; Grosser and Gmitter, 1990; Sanghera et al., 2011). Poncirus has been used in many intergeneric crosses to increase cold tolerance, although the fruit of Poncirus itself is inedible (Barrett, 1990; Gmitter, 1994; Tignor et al., 1998). The USDA citrus breeding program has been using Poncirus in some hybridizations for many years, specifically to enhance cold-hardiness (Barrett and Young, 1982; Tignor et al., 1998) and many advanced selections now include Poncirus in their pedigree, although so far none has been released as cultivars.

Six parental genotypes that were in the pummelo $\times$ mandarin hybrid or sour orange group had less than $25 \%$ dieback, but four pummelo $\times$ mandarin hybrids and sour orange parental types and many pummelos and mandarins showed substantial dieback. Somewhat surprising in this study was the minimal cold damage to seedlings of Mato Buntan pummelo, because pummelos are generally considered more "tropical" than mandarins and sweet oranges. However, Mato Buntan is the seed parent of Tanikawa Butan, which is relatively more cold-tolerant than most pummelos (Hodgson, 1967), and pummelos are completely monoembryonic; therefore, each of the seedlings in our test were unique hybrids. These results suggest that judicious breeding through selection of appropriate parents may confer greater cold-hardiness even through conventional citrus breeding, because pummelo and mandarin provide the primary genetic contribution to most commercial citrus scions.

\section{Literature Cited}

Barkley, N.L.A. 2003. Genetic diversity in a citrus germplasm collection characterized with simple sequence repeat markers. PhD diss., Univ. Calif., Riverside, CA.

Barrett, H.C. 1990. US 119, an intergeneric hybrid citrus scion breeding line. HortScience 25:1670-1671.

Barrett, H.C. and R. Young. 1982. New sources of cold hardiness for citrus breeding. HortScience 17:886.

Bayer, R.J., D.J. Mabberley, C. Morton, C.H. Miller, I.K. Sharma, P. Pfeil, S. Rich, R. Hitchcock, and S. Sykes. 2009. A molecular phylogeny of the orange subfamily (Rutaceae: Aurantioideae) using nine cpDNA sequences. Amer. J. Bot 96:668-685.

Bourgeois, W.J., A.J. Adams, and D.R. Snipe. 1990. Effectiveness of scaffold branch irrigation for freeze protection of Louisiana citrus during 1989 freeze. Proc. Fla. State Hort. Soc. 103: 62-64.

Champ, K.I., V.J. Febres, and G.A. Moore. 2007. The role of CBF transcriptional activators in two Citrus species (Poncirus and Citrus) with contrasting levels of freezing tolerance. Physiol. Plant. 129:529-541.

Cooper, W.C., S. Taylor, and N. Maxwell. 1955. Preliminary studies on cold hardiness in citrus as related to cambial activity and bud growth. Proc. Rio Grande Valley Hort. Soc. 9:2-16.

Davies, F.S. and L.G. Albrigo. 1994. Citrus, p. 134-135. In: Davies, F.S. and L.G. Albrigo (eds.) Crop production science in horticulture series. CAB International, Wallingford, UK.

Davies, F.S., L.K. Jackson, and L.W. Rippetoe. 1984. Low volume irrigation and tree wraps for cold protection of young Hamlin orange trees. Proc. Fla. State Hort. Soc. 97:25-27.

Ebel, R.C., M.L. Nesbitt, W.A. Dozier, and F. Dane. 2008. Freeze risk and protection measures of Satsuma mandarins grown in the southeastern United States. HortScience 43: 287-289.

Ebel, R.C., M.L. Nesbitt, W.A. Dozier, J.K. Lindsey, and B.S. Wilkins. 2005. A temperature index model to estimate long-term freeze-risk of Satsuma mandarins grown on the Northern coast of the Gulf of Mexico. J. Amer. Soc. Hort. Sci. 130: 500-507.

Fleming, G.H., O. Olivares-Fuster, S.F. Del-Bosco, and J.W. Grosser. 2000. An alternative method for the genetic transformation of sweet orange. In Vitro Cellular Dev. Biol. Plant 36:450-455.

Florida Automated Weather Network (FAWN). 2014. Archived Weather Data. Mar. 2014. <http:// fawn.ifas.ufl.edu $>$.

Frost, H.B. and R.K. Soost. 1968. Seed reproduction: Development of gametes and embryos, $\mathrm{p}$. 290-324. In: Reuther, W., L.D. Batchelor, and H.J. Webber (eds.). The citrus industry. Vol. 2. Anatomy, physiology, genetics, and reproduction. Univ. California, Berkeley, CA.

Gmitter, F.G., Jr. 1994. Contemporary approaches to improving citrus cultivars. HortTechnology 4:206-210.

Grosser, J.W. and F.G. Gmitter, Jr. 1990. Protoplast fusion and citrus improvement. Plant Breed. Rev. 8:339-374.

Grosser, J.W., F.G. Gmitter, Jr., and J.L. Chandler. 1998. Intergeneric somatic hybrid plants of Citrus sinensis cv. Hamlin and Poncirus trifoliata cv. Flying dragon. Plant Cell Rpt. 7:5-8.

Grosser, J.W., F.G. Gmitter, Jr., N. Tusa, and J.L. Chandler. 1990. Somatic hybrid plants from sexually incompatible woody species: Citrus reticulata and Citropsis gilletiana. Plant Cell Rpt. 8:656-659.

Grosser, J.W., P. Ollitrault, and O. Olivares-Fuster. 2000. Invited review: Somatic hybridization in Citrus: An effective tool to facilitate variety improvement. In Vitro Cell Dev. Biol. Plant 36:434-449.

He, L.G., H.L. Wang, D.C. Liu, Y.J. Zhao, M. Xu, M. Zhu, and Z.H. Sunday. 2012. Isolation and expression of a cold-responsive gene $P t C B F$ in Poncirus trifoliata and isolation of citrus $C B F$ promoters. Biol. Plant. 56:484-492.

Hendershott, C.H. 1962. The response of orange trees and fruits to freezing temperatures. Proc. Amer. Soc. Hort. Sci. 80:247-254.

Hodgson, R.W. 1967. Horticultural varieties of Citrus, p. 431-587. In: Reuther, W., H.J. Webber, and L.D. Batchelor (eds.). The citrus industry volume 1. Univ. Calif. Press, Berkeley, CA, and Los Angeles, CA.

Huang, Y., Y. Si, and F. Dane. 2011. Impact of grafting on cold responsive gene expression in 
Satsuma mandarin (Citrus unshiu). Euphytica 177:25-32.

Jackson, L.W., D.W. Buchanan, and L.W. Rippetoe. 1983. Comparison of wraps and soil banks for Citrus cold protection. Proc. Fla. State Hort. Soc. 96:29-31.

Ketchie, D.O. 1969. Methods of determining cold hardiness and cold injury in citrus. Proc. First Intl. Citrus Symp. 2:559-563.

Ladizinsky, G. 1992. Crossability relations, p. 1531. In: Kallo, G. and J.B. Chowdhury (eds.). Distant hybridization in crop plants. SpringerVerlag, Berlin, Germany.

Lang, P., C. Zhang, R.C. Ebel, F. Dane, and W.A. Dozier. 2005. Identification of cold acclimated genes in leaves of Citrus unshiu by mRNA differential display. Gene 359:111-118.

Long, G., J. Song, Z. Deng, J. Liu, and L. Rao. 2012. Ptcorp gene induced by cold stress was identified by proteomic analysis in leaves of Poncirus trifoliata. Mol. Biol. Rpt. 39:5859-5866.

Luth, D. and G.A. Moore. 1999. Transgenic grapefruit plants obtained by Agrobacterium tumefaciens-mediated transformation. Plant Cell Tissue Organ Cult. 57:219-222.

Medina-Filho, H., P. Bordignon, and R.M.L. Ballve. 1998. Sunkifolias and Buxisunkis: Sexually obtained reciprocal hybrids of Citrus sunki $\times$ Serverinia buxifolia. Genet. Mol. Biol. 21:129-133.

Miller, K.A. 1991. Response of Florida citrus growers to the freezes of the 1980s. Clim. Res. 1:133-144.

Moore, G. A., C.C. Jacono, J.L. Neidigh, S.D. Lawrence, and K. Cline. 1992. Agrobacteriummediated transformation of citrus stem segments and regeneration of transgenic plants. Plant Cell Rpt. 11:238-242.

National Agricultural Statistics Services. 2012. State Agriculture Overview. Mar. 2014. <http:// www.nass.usda.gov>.

Nisbitt, M.L., R.C. Ebel, W.A. Dozier, N.R. McDaniel, and D.G. Himelrick. 2000. Performance of Satsuma mandarin protected from freezing temperatures by microsprinkler irrigation. HortScience 37:871-877.

Penjor, T., M. Yamamoto, M. Uehara, M. Ide, N. Matsumoto, R. Matsumoto, and Y. Magano. 2013. Phylogenetic relationships of Citrus and its relatives based on matK gene sequences. PLoS One 8:1-13.

Rieger, M., G. Krewer, P. Lewis, M. Linton, and T. McClendon. 2003. Field evaluation of cold hardy citrus in coastal Georgia. HortTechnology 13:540-544.

Sahin-Çevik, M. and G.A. Moore. 2006. Identification and expression analysis of cold-regulated genes from the cold-hardy Citrus relative Poncirus trifoliata (L.). Raf. Plant Mol. Biol. 62:83-97.

Sanghera, G.S., S.H. Wani, W. Hussain, and N.B. Singh. 2011. Engineering cold stress tolerance in crop plants. Curr. Genomics 12:30-43.

SAS Institute Inc. 2013. JMP ${ }^{\circledR}$, Version 11. Cary, NC. Soost, R.K. and J.W. Cameron. 1975. Citrus, p. 507-540. In: Janick, J. and J.N. Moore (eds.). Advances in fruit breeding. Purdue University Press, West Lafayette, IN.

Soost, R.K. and M.L. Roose. 1996. Citrus, p. $257-$ 323. In: Janick, J. and J.N. Moore (eds.). Fruit breeding: Tree and tropical fruits. John Wiley, New York, NY.
Tignor, M.E., F.S. Davies, and W.B. Sherman. 1998. Freezing tolerance and growth characteristics of USDA intergeneric citrus hybrids US119 and selection 17-11. HortScience 33:744-748.

UC IPM Online. 2014. Weather, models, \& degreedays. Mar. 2014. <http://www.ipm.ucdavis. edu/WEATHER/index.html $>$.

Webber, C.A., G.A. Moore, Z. Deng, and F.G. Gmitter, Jr. 2003. Mapping freeze tolerance quantitative trait loci in Citrus grandis $\times$ Poncirus trifoliata F1 pseudo-test crossing using molecular markers. J. Amer. Soc. Hort. Sci. 128:508-514.

Yelenosky, G. 1975. Cold hardening in Citrus stems. Plant Physiol. 56:540-545.

Yelenosky, G. 1985. Cold hardiness in citrus. Hort. Rev. 7:201-238.

Yelenosky, G. 1996. An overview of Florida Citrus freeze survival. Proc. Fla. State Hort. Soc. 109:118-123.

Yelenosky, G. and J.C.V. Vu. 1992. Ability of 'Valencia' sweet orange to cold-acclimate on cold-sensitive citron rootstock. HortScience 27:1201-1203.

Yao, J. L., J.H. Wu, A.P. Gleave, and B.A.M. Morris. 1996. Transformation of citrus embryogenic cells using particle bombardment and production of transgenic embryos. Plant Sci. 113:175-183.

Zhang, C.K., P. Lang, F. Dane, R.C. Ebel, N.K. Singh, R.D. Locy, and W.A. Dozier. 2005. Cold acclimation induced genes of trifoliate orange (Poncirus trifoliata). Plant Cell Rpt. 23:764-769. 